Bird evolution in the Eocene: climate change in Europe and a Danish fossil fauna.

Lindow, Bent Erik Kramer; Dyke, G.J.

Published in:

Biological Reviews

Publication date:

2006

Document version

Publisher's PDF, also known as Version of record

Citation for published version (APA):

Lindow, B. E. K., \& Dyke, G. J. (2006). Bird evolution in the Eocene: climate change in Europe and a Danish fossil fauna. Biological Reviews, 81, 1-16. 


\title{
Bird evolution in the Eocene: climate change in Europe and a Danish fossil fauna
}

\author{
Bent E. K. Lindow ${ }^{1,2}$ and Gareth J. Dyke ${ }^{1 *}$ \\ ${ }^{1}$ School of Biology and Environmental Science, University College Dublin, Belfield, Dublin 4, Ireland \\ ${ }^{2}$ Geological Museum, Natural History Museum of Denmark, Oster Voldgade 5-7, DK-1350, Copenhagen K, Denmark
}

(Received 11 August 2005; revised 9 May 2006; accepted 12 May 2006)

\begin{abstract}
ABSTRAGT
The pattern of the evolutionary radiation of modern birds (Neornithes) has been debated for more than 10 years. However, the early fossil record of birds from the Paleogene, in particular, the Lower Eocene, has only recently begun to be used in a phylogenetic context to address the dynamics of this major vertebrate radiation. The Cretaceous-Paleogene (K-P) extinction event dominates our understanding of early modern bird evolution, but climate change throughout the Eocene is known to have also played a major role. The Paleocene and Lower Eocene was a time of avian diversification as a result of favourable global climatic conditions. Deteriorations in climate beginning in the Middle Eocene appear to be responsible for the demise of previously widespread avian lineages like Lithornithiformes and Gastornithidae. Other groups, such as Galliformes display replacement of some lineages by others, probably related to adaptations to a drier climate. Finally, the combination of slowly deteriorating climatic conditions from the Middle Eocene onwards, appears to have slowed the evolutionary rate in Europe, as avian faunas did not differentiate markedly until the Oligocene. Taking biotic factors in tandem with the known Paleogene fossil record of Neornithes has recently begun to illuminate this evolutionary event. Well-preserved fossil taxa are required in combination with ever-improving phylogenetic hypotheses for the interrelationships of modern birds founded on morphological characters. One key avifauna of this age, synthesised for the first time herein, is the Lower Eocene Fur Formation of Denmark. The Fur birds represent some of the best preserved (often in three dimensions and with soft tissues) known fossil records for major clades of modern birds. Clear phylogenetic assessment of these fossils will prove critical for future calibration of the neornithine evolutionary timescale. Some early diverging clades were clearly present in the Paleocene as evidenced directly by new fossil material alongside the phylogenetically constrained Lower Eocene taxa. A later Oligocene radiation of clades other than Passeriformes is not supported by available fossil data.
\end{abstract}

Key words: Aves, Eocene, climate change, Paleogene, Denmark, Fur Formation, Neornithes, phylogeny.

\section{CONTENTS}

I. Introduction

II. The Eocene Epoch: climate, faunal change and extinctions

(1) Early Eocene

(2) Middle Eocene

(3) Late Eocene

(4) Early Oligocene

III. The Early Eocene Fur Formation of Denmark: some of the earliest modern birds

(1) Geological setting

(2) Faunal review

(a) Palaeognathae, Galloanserae, shorebirds and 'waterbirds'

(b) Parrots and 'higher land birds' 
IV. Addressing the Eocene avian radiation

(1) Climate change

(2) A question of phylogenetic scale

V. Conclusions

VI. Acknowledgements

VII. References

\section{INTRODUGTION}

The study of fossil birds continues to be one of the most dynamic fields of evolutionary biology - the evolution of avian flight, the phylogenetic relationships of the major clades, and the pattern of the modern radiation of birds (encompassing the extant 'orders' and 'families') are just some of the topics that have focused research efforts over the last decades. Although the fossil record of archaic birds from the Mesozoic Era (the time span comprising the Triassic-Jurassic-Cretaceous) continues to improve, other than in basic shape (Fig. 1), precise phylogenetic details of the modern avian radiation remain debated. In tandem with improvements in the fossil record, a great deal of research effort has attempted to elucidate the evolutionary history of the more than 10000 living species of birds using morphological and molecular data. It is known, for example, that some lineages of modern birds (Neornithes) existed in the Cretaceous, prior to the Cretaceous-Paleogene (K-P) extinction event 65 million years ago (MYA) (Hope, 2002; Clarke et al., 2005). How many and how extensive their evolutionary diversification was remains unclear. What is clear, however, is that the record of Neornithes improves dramatically in the earliest Paleogene, even though few wellpreserved fossils are yet known from the earliest stages of this period (the Paleocene). By the time of the Early and Middle Eocene (approximately 55-37 MYA) the fossil record of modern birds is well-represented and abundant. Well-known Eocene deposits such as Messel (Germany) and the London Clay Formation (UK) document neornithine diversification in a European context. Lineage dynamics at the base of modern birds and the evolution of the group subsequent to the K-P event still remain unclear.

Well-preserved fossils that can be used to document the earliest evolutionary phases of Neornithes are very rare - fossils are needed that preserve enough anatomical features to be confidently included in phylogenetic analyses founded on extant taxa. Few anatomically modern bird taxa consisting of more than single fossil bones have ever been recognised from the latest Mesozoic, across the K-P boundary (Chiappe \& Dyke, 2002; Clarke et al., 2005), and into the very earliest stages of the Paleogene (Dyke \& van Tuinen, 2004). What has been described, especially from the Cretaceous, is highly fragmentary (Unwin, 1993; Hope, 2002) and is mostly phylogenetically uninformative (Chiappe \& Dyke, 2002; Dyke \& van Tuinen, 2004). At the time of writing only the modern 'waterfowl' clade Anseriformes (comprising the extant screamers, ducks and geese) boasts a well-preserved, phylogenetically constrained representative from the late Cretaceous (Clarke et al., 2005). By implication then, Galliformes (the sistertaxon of Anseriformes) and Neoaves (the sister-taxon of Galloanserae) must also have been present during the late Cretaceous.

This large temporal paradox between the now abundant record of Cretaceous archaic non-modern birds (Chiappe, 1995; Feduccia, 1999, 2003; Chiappe \& Dyke, 2002; Chiappe \& Witmer, 2002; Fountaine et al., 2005) and their 'modern' counterparts found in rocks of early Eocene age (Dyke, 2001 a; Mayr, 2001; Dyke \& Gulas, 2002; Dyke \& van Tuinen, 2004; Mayr, 2005) has confounded interpretations of neornithine evolution across the K-P boundary, and has also meant that the basal divergences of modern birds have remained largely unresolved on the basis of osteological characters. In spite of the absence of characters drawn from good, well-represented fossil material, many years of anatomical work has proved unsuccessful in unravelling the relationships of extant birds (Cracraft \& Clarke, 2001; Cracraft et al., 2004; Mayr, 2005) (Fig. 1). Perhaps more surprisingly, a similar pattern occurs in recent molecular analyses - no single well-resolved tree for Neornithes has yet been produced using this muchtouted data source either, possibly reflecting short internodes resulting from rapid radiation at the base of modern birds (Feduccia, 1995, 2003; Poe \& Chubb, 2004; Fain \& Houde, 2004).

The single overriding issue pertinent to this debate is simply that few deposits yielding well-preserved fossils of early Paleogene age are known (reviewed in Mlíkovsky, 1996; Mayr, 2005). In this paper, our aim is to set the scene for bird evolution in the Paleogene by describing the changes in climate that took place during the Eocene and early Oligocene across Europe, and to present an initial report of a hitherto mostly overlooked European fossil-bird-bearing deposit, the lowermost Eocene Fur Formation of Denmark. This formation has produced well-preserved bird fossils in some numbers over recent years. Because some taxa from this deposit preserve an exceptional level of anatomical detail, they are likely to prove highly informative to our understanding of early neornithine evolution. Another motivation for presenting this report is that the fossil birds of the Fur Formation remain little known in the scientific literature, warranting only cursory discussion in previous reviews of the early neornithine fossil record (Dyke \& van Tuinen, 2004; Mayr, 2005) and lineage dynamics (Cracraft, 2001). Classic compilations of the modern avian fossil record (e.g. Olson, 1985) do not mention taxa from this deposit at all. Thus, taken in combination with other fossil modern birds of similar age from elsewhere in Europe and evaluated in a phylogenetic context, the birds from the Fur Formation can provide critical insights into the shape of the neornithine 


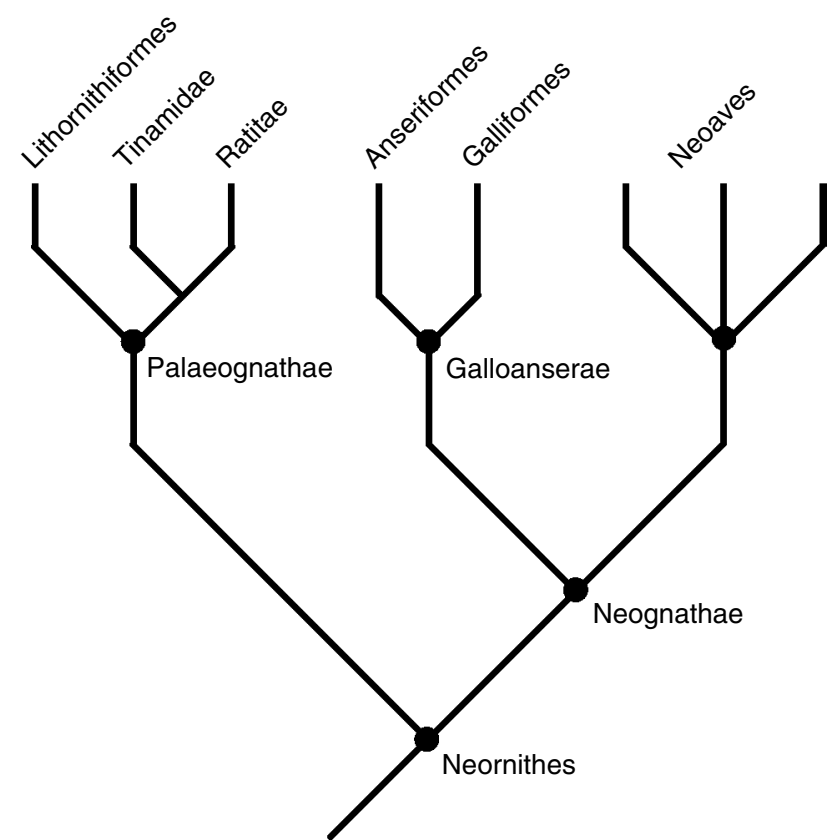

Fig. 1. The shape of the modern avian radiation based on a variety of morphological and molecular sources (see Cracraft et al., 2004; Dyke \& van Tuinen, 2004). The depth of this radiation into the Cretaceous remains in question.

evolutionary radiation in the earliest Paleogene. With a temporally well-calibrated fossil record it is also possible to consider the influence of climate change across Europe on the early evolution and diversification of modern birds.

\section{THE EOGENE EPOCH: CLIMATE, FAUNAL GHANGE AND EXTINGTIONS}

The Eocene Epoch spans the time period from 55.8 to 33.9 MYA and is divided into three parts: Early, Middle and Late (Gradstein et al., 2004). We know that during this Epoch one of the most important overall climatic changes to occur during the entire Cenozoic (65 MYA to recent) took place: gradual global cooling. In the earlier parts of the Eocene, global climate has been considered generally moist and hot (a so-called 'greenhouse' climate; Prothero, $1994 a, b)$ supporting a high diversity of taxa, including birds. Diverse Lower Eocene avian faunas are well known from Europe (e.g. London Clay Formation, UK; Fur Formation, Denmark) and North America (e.g. Green River Formation, Wyoming; Willwood Formation, Montana), in particular. By contrast, by the end of the Eocene global climates had cooled to a more temperate 'icehouse' regime considered to have supported a lower diversity of taxa (Prothero, $1994 a, b)$. Unfortunately, temporal resolution of the avian fossil record in the later Eocene is not good enough to address this directly (G. Dyke, unpublished data). Gradual global cooling was a result of changes in oceanic circulation brought on by the onset of Antarctic glaciation and changes in the greenhouse gas content of the atmosphere (Prothero, $1994 a, b)$. Throughout the majority of the Eocene Europe remained an archipelago on the edge of the warm Tethys Sea and only underwent minor changes in drying and cooling compared to North America (Prothero, 1994a). It has already been shown that understanding climate change prior to and throughout the Eocene and Oligocene is critical to our treatment of avian evolution (Blondel \& MourerChauviré, 1998)

\section{(1) Early Eocene}

The Early Eocene spans the time period from 55.8 to 48.6 MYA and encompasses the Ypresian stage (Gradstein et al., 2004). The onset of the Eocene period is marked by rapid $\mathrm{CO}_{2}$ - and $\mathrm{CH}_{4}$-induced global warming, which lasted less than 10000 years (Schmitz et al., 2004). This was probably the result of large-scale release of methane hydrates from the seafloor (Bains, Corfield \& Norris, 1999; Thomas et al., 2002) triggered by extensive basaltic volcanism in the North Atlantic area (Schmitz et al., 2004; Svensen et al., 2004). The gas release triggered greenhouse conditions, which resulted in some of the highest palaeotemperatures recorded on the planet during the Cenozoic; the so-called 'Early Eocene climatic optimum' which lasted at least two million years (Zachos et al., 2001). During this event, marine nanoplankton suffered extinction events or underwent periods of massive faunal turnover (Kennett \& Stott, 1991; Kelly et al., 1996; Thomas, 1998; Crouch et al., 2001) and terrestrial mammal faunas are also thought to have experienced turnovers with new groups replacing archaic ones (Gingerich, 2003).

In the aftermath of this climatic optimum, Early Eocene terrestrial climates are considered to have been generally warm and moist, with tropical climates in the mid-latitude regions and a frost-free temperate climate in the polar regions (Prothero, $1994 a, b)$. Global sea level was high, and ocean temperatures were much warmer than today, with tropical seas extending north and south of the equator beyond $50^{\circ}$ northern and southern latitude (Prothero, 1994a). There was little overall difference in water temperature between high and low latitudes due to the mixing of higher latitude and equatorial waters (Kennett, 1977; Kennett \& Stott, 1990; Prothero, $1994 a, b)$.

At the beginning of the Early Eocene (approximately 55 MYA) Europe was connected to North America across the Greenland-Scotland ridge (McKenna, 1980, 1983) resulting in many similarities in the mammalian faunas (Prothero, 1994a). By the time of the Late Eocene (approximately $37 \mathrm{MYA}$ ) this connection had closed as a result of the opening of the northernmost Atlantic Ocean (Prothero, 1994a). European floras at this time were tropical (Collinson, 1983; Boulter, 1984; Collinson \& Hooker, 1987).

\section{(2) Middle Eocene}

The Middle Eocene spans the period from 48.6 to 37.2 MYA and encompasses the Lutetian and Bartonian stages (Gradstein et al., 2004). Terrestrial climates of the 
northern hemisphere in Middle Eocene times have been considered to be warm overall with subtropical conditions and small variations in annual mean temperature (Prothero, $1994 a, b)$. At this time, Western Europe was separated from North America as a result of the opening of the northernmost Atlantic and rising sea level, and an endemic mammalian fauna developed (Collinson \& Hooker, 1987; Collinson, 1992; Prothero, 1994a). Floras across Europe are thought to have remained tropical (Collinson \& Hooker, 1987, Collinson, 1992).

Close to the end of the Middle Eocene a drying and cooling event took place, which drastically changed the flora and resulted in a major extinction event among treeliving and leaf-eating mammals adapted to a forest habitat (Prothero, 1994a,b). Across Europe floristic analyses have indicated a progressive cooling of temperature resulting in the extinction of many tropical and subtropical plants by the end of the Eocene and their subsequent replacement by deciduous forms (Collinson, Fowler \& Boulter, 1981). Many soft-browsing herbivores, tree-dwelling primates and insectivores became extinct, replaced by coarser-browsing forms (Collinson \& Hooker, 1987; Hooker, 1992; Legendre \& Hartenberger, 1992). The termination of the Middle Eocene was marked by the greatest marine extinction event to take place during the Cenozoic. Many taxa of marine single-celled organisms and invertebrates became extinct, with tropical forms especially severely hit (Prothero, $1994 a, b)$. Overall global cooling at this time was probably caused again by changes in oceanic circulation or by buildup of ice in the Antarctic (Prothero, 1994a).

\section{(3) Late Eocene}

The Late Eocene spans the period from 37.2 to 33.9 MYA and encompasses the Priabonian stage (Gradstein et al., 2004). At the beginning of the Late Eocene global temperatures decreased slightly in comparison with the Middle Eocene (Prothero, $1994 a, b$ ). Across Europe tropical forests were replaced with subtropical ones (Collinson \& Hooker, 1987; Collinson, 1992). The end of the Eocene itself is only marked by a minor marine extinction event during which a few taxa of ocean-going single-celled organisms became extinct (Prothero, $1994 a, b)$.

\section{(4) Earliest Oligocene}

The Early Oligocene (33.9-28.4 MYA) encompasses the Rupelian stage (Gradstein et al., 2004); at this time climates are known to have rapidly become colder and drier accompanied by a drastic increase in mean annual range of temperatures (Prothero, 1994a,b). European forests in the earliest Oligocene are a mixture of deciduous and evergreen types indicating a warm-temperate-seasonal climate (Collinson \& Hooker, 1987; Collinson, 1992), while the mammal fauna indicates more open and dry savanna-like habitats (Legendre, 1987, 1988).

This major Oligocene cooling and drying event is also supported by analysis of oxygen isotopes from marine sediments which point to a sudden drop of $5-6{ }^{\circ} \mathrm{C}$ in the annual mean sea temperature of (Miller, Fairbanks \& Mountain,
1987), probably due to a major ice advance on Antarctica (Miller, Wright \& Fairbanks, 1991). This ice advance itself was the result of the increasing cooling of Antarctica due to the development of a circum-Antarctic current, which kept the southern polar region cool and prevented the mixing of currents with warmer equatorial waters (Frakes \& Kemp, 1972; Kennett, 1977; Prothero, $1994 a, b)$. At the same time, in the earliest Oligocene, a sea passage opened between Greenland and Norway allowing cold Arctic waters to penetrate into the warmer Atlantic (Talwani \& Eldholm, 1977; Thiede, Eldholm \& Taylor, 1989; Berggren, 1992; Miller, 1992). Temperatures across Europe were substantially colder than in the Lower Eocene.

This sudden cooling in the Oligocene resulted in a great mass extinction, during which many marine single-celled and invertebrate taxa that had survived the previous endMiddle Eocene extinction disappeared. Again, warm-wateradapted forms suffered especially heavy losses (Prothero, $1994 a, b)$, as did the European land-mammal fauna ('La Grande Coupure' of Stehlin, 1909). Extinctions among mammals were especially marked amongst 'archaic' groups adapted to a forest habitat as well as among tree-dwelling forms. A number of mammal groups were replaced by Asian immigrants in the form of large ground-dwelling animals adapted to open habitats and rodents adapted to grain- and seed-eating (Prothero, $1994 a, b$ ). These immigrant taxa probably arrived through a corridor formed by the Alpine uplift (Heissig, 1979; Prothero, 1994a).

\section{THE EARLY EOGENE FUR FORMATION OF DENMARK: SOME OF THE EARLIEST MODERN BIRDS}

Fossil fish, reptiles, insects and plants have been collected from the Lower Eocene Fur Formation for 140 years (Bonde, 1987). Over the course of the last two decades, just a few remains of fossil birds have been discovered and described from the Fur Formation (see Kristoffersen, 2002b). In contrast with the preservation style of bird remains from many other Lower Eocene sites around the world (Dyke \& van Tuinen, 2004), a good proportion of the Danish fossils are exceptionally well-preserved, and three-dimensionally articulated.

\section{(1) Geological setting}

Sediments that comprise the Fur Formation outcrop in northwest Jutland, Denmark (Fig. 2) consist of approximately $60 \mathrm{~m}$ thickness of marine diatomite (Pedersen \& Surlyk, 1983). Interbedded within the Fur Formation are more than 170 layers of volcanic ash, which derive from volcanic eruptions during the opening of the NorwegianGreenland Sea at the beginning of the Lower Eocene (Larsen, Filton \& Pedersen, 2003). Previous authors (e.g. Pedersen \& Surlyk, 1983; Kristoffersen, 2002b) have assigned the Fur Formation either a Palaeocene or a Palaeocene-Eocene age. However, the formation should now be considered exclusively Lower Eocene, as the 


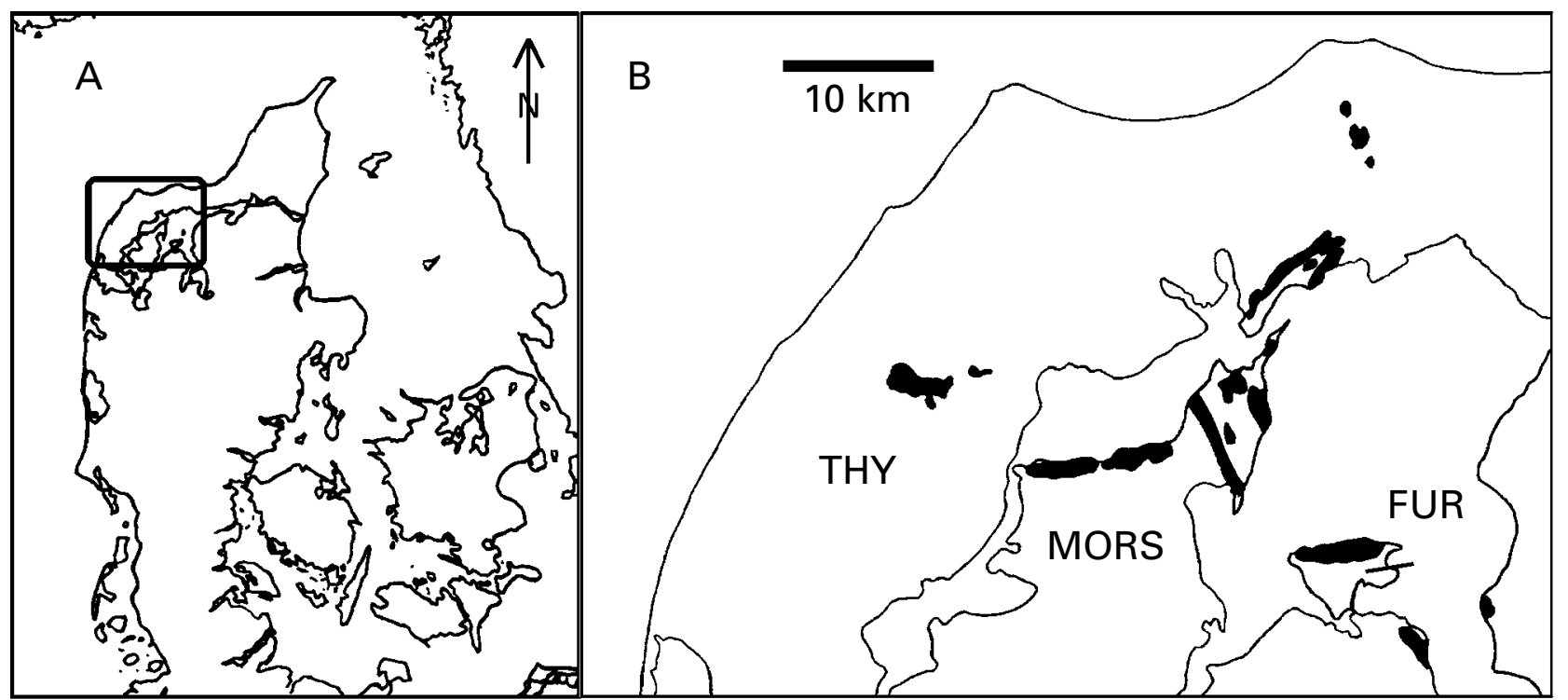

Fig. 2. (A) Map of western and central Denmark showing location of map B. (B) Outcrops of the Fur Formation (black) in northwest Jutland (modified from Pedersen \& Surlyk, 1983).

Paleocene/Eocene boundary has been identified in the underlying Stolleklint Clay Member of the Ølst Formation (Heilmann-Clausen \& Schmitz, 2000; Beyer, HeilmanClausen \& Abrahamsen, 2001; Schmitz et al., 2004). This revised age is also supported by ${ }^{39} \mathrm{Ar} /{ }^{40} \mathrm{Ar}$-dating of two of the ash layers within the Fur Formation, which has yielded ages of 54.5 and 54.0 MYA (Chambers et al., 2003).

The sediments of the Fur Formation were deposited in a local region of the North Sea basin where extensive upwelling of nutrient-rich bottom water resulted in extraordinary blooms of diatoms (silicaceous-shelled algae) (Pedersen \& Surlyk, 1983). Diatom shells rained down on the sea floor, forming a fine-grained diatomite sediment, which consists of 45-65 weight per cent diatoms, 30-45 per cent clay minerals and approximately 10 percent volcanic dust (Pedersen et al., 2004). Because the formation was deposited at water depths below the storm wave base, under anoxic or slightly oxic bottom conditions, well-preserved, articulated vertebrate fossils, including birds, are relatively common (Pedersen \& Surlyk, 1983; Bonde, 1987). At certain horizons within the formation calcareous carbonate concretions occur, sometimes in more-or-less continuous layers (Pedersen \& Surlyk, 1983). These concretions 'grew' in the sea-floor sediment, often around fossils, a relatively short time after deposition of the sediment (Pedersen \& Surlyk, 1983; Pedersen \& Buchardt, 1996). The concretions are readily collected at the surface, where they have weathered out of the diatomite cliffs.

Two distinct modes of fossil preservation occur within the Fur Formation: within the carbonate concretions or as imprints in the diatomite. Although the imprinted fossils are often slightly flattened (Fig. 3A), the sediment is fine-grained enough to allow details to be picked out on imprints on a 1/20 mm-scale (B. Lindow, personal observations). Fossil remains from within the carbonate concretions are threedimensionally preserved as the hard concretions protected their contents from compaction (Pedersen \& Surlyk, 1983). Imprints of feathers and soft tissue are not uncommon in the Fur Formation and $40 \%$ of all bird fossils from the formation are carbonised imprints of lone feathers or feather imprints in relation to bones (Fig. 3B) (Kristoffersen, $2002 b)$.

\section{(2) Faunal review}

Despite originating from a marine deposit, most of the birds that have been identified and described from the Fur Formation would have lived on land; they were adapted to terrestrial and perching modes of life. Of the entire suite of fossils in this review (Table 1), only very few can be considered to belong to modern 'orders' adapted to an aquatic or marine lifestyle (Kristoffersen, 2002b). A preliminary survey of the avian diversity preserved in the Fur Formation recorded one extinct avian 'order' alongside representatives of 12 (of the approximately 26; sensu Monroe \& Sibley, 1993) extant 'orders' (Kristoffersen, 2002 b).

Since the earliest published reports of a bird fossil from the Fur Formation (Hoch, 1972, 1975), technical papers dealing with these Danish birds have intermittently appeared over the course of the last two decades (e.g. Hoch \& Pedersen, 1983; Hoch, 1997; Kristoffersen, 1997 a, b, 1999, $2002 a$; Dyke, Waterhouse \& Kristoffersen, 2004). Some of the Fur Formation avifauna formed the subject of an unpublished PhD thesis (Kristoffersen, $2002 b$ ), based at the University of Copenhagen's Geologisk Museum (abbreviated MGUH) where many of these fossils are reposited.

Here we build on earlier publications that have considered one or more of the Fur Formation fossil birds to provide an accessible synthesis of the diversity from this deposit that has been presented in the primary literature to date. Taxonomic identification of specimens is ongoing and at this stage we do not present phylogenetic evaluations of 


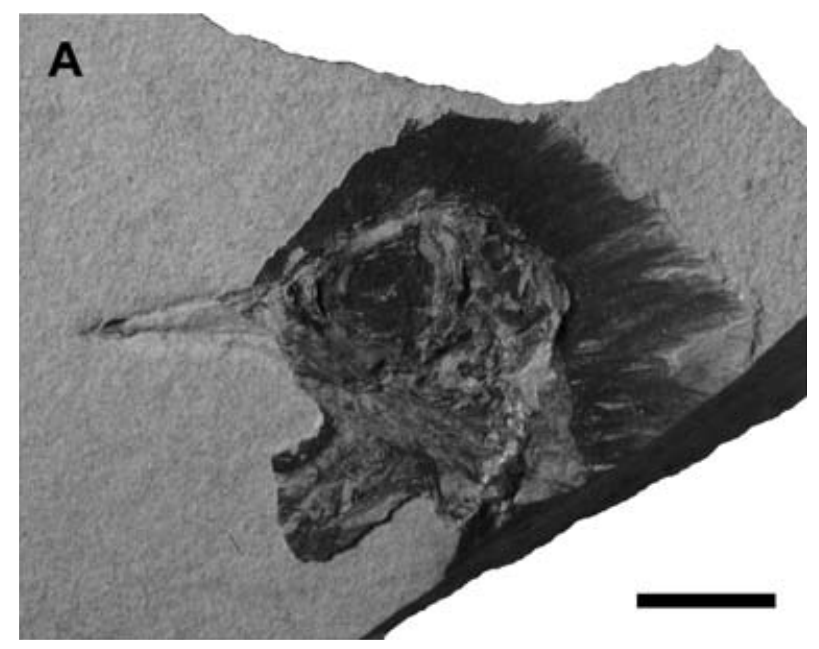

Table 1. List of avian taxa currently recognised from the Fur Formation; extinct 'orders' and 'families' marked with a †. Based on Hoch (1975), Houde (1988), Kristoffersen (1999, $2002 a, b)$, Dyke et al. (2004), Leonard et al. (2005) and S. Bertelli, L. Chiappe, G. Dyke and B. Lindow (unpublished data)

\section{$\dagger$ Lithornithiformes \\ $\dagger$ Lithornithidae \\ Lithornis vulturinus \\ Lithornis sp. \\ gen. et sp. indet. 1 \\ gen. et sp. indet. 2 \\ gen. et sp. indet. 3 \\ Galliformes \\ $\dagger$ Gallinuloididae cf. Gallinuloides sp. \\ $\uparrow$ Paraortygidae Gen. et spec. indet.}

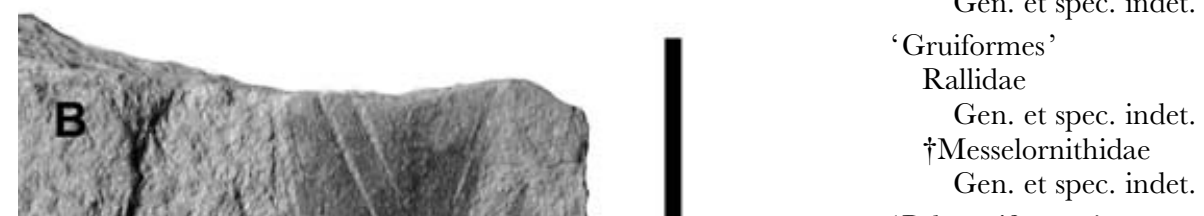

'Pelecaniformes' n. Gen. et spec.

Charadriiformes

n. Gen. et spec.

Gen. et spec. indet.

Psittaciforme n. Gen. et spec.

Pseudasturidae ? Pseudastur sp.

Musophagiformes Gen. et spec. indet. 1 Gen. et spec. indet. 2 Gen. et spec. indet. 3

Coliiformes

$\uparrow$ Sandcoleidae

Chascacolius cf. oscitans Eoglaucidium sp.

?Strigiformes Gen. et spec. indet.

Apodiformes

Hemiprocnidae Eocypselus vincenti

'Caprimulgiformes' Gen. et spec. indet.

Coraciiformes

Gen. et spec. indet. 1 Gen. et spec. indet. 2 Gen. et spec. indet. 3

Fig. 3. (A) Fossil bird head from the Fur Formation preserved as partial imprint in calcareous diatomite (MGUH DK 200). Soft tissue has been preserved as carbonised imprints. Scale bar $=1.0 \mathrm{~cm}$. (B) Fossil feather (MGUH DK 253a) preserved as carbonised imprint in diatomite. Scale bar $=2.0 \mathrm{~cm}$.

fossils in a cladistic context; this represents an area of future work, being conducted in collaboration with S. Bertelli and L. Chiappe (unpublished data). Instead our review is ordered roughly according to standard avian taxonomic checklists (e.g. Monroe \& Sibley, 1993), building from the base of the modern bird tree (Palaeognathae, Galloanserae

Trogoniformes

Trogonidae Septentrogon madseni Gen. et spec. indet. 1 Gen. et spec. indet. 2 Gen. et spec. indet. 3

Neornithes incertae sedis

Primoscenidae

Gen. et spec. indet. 


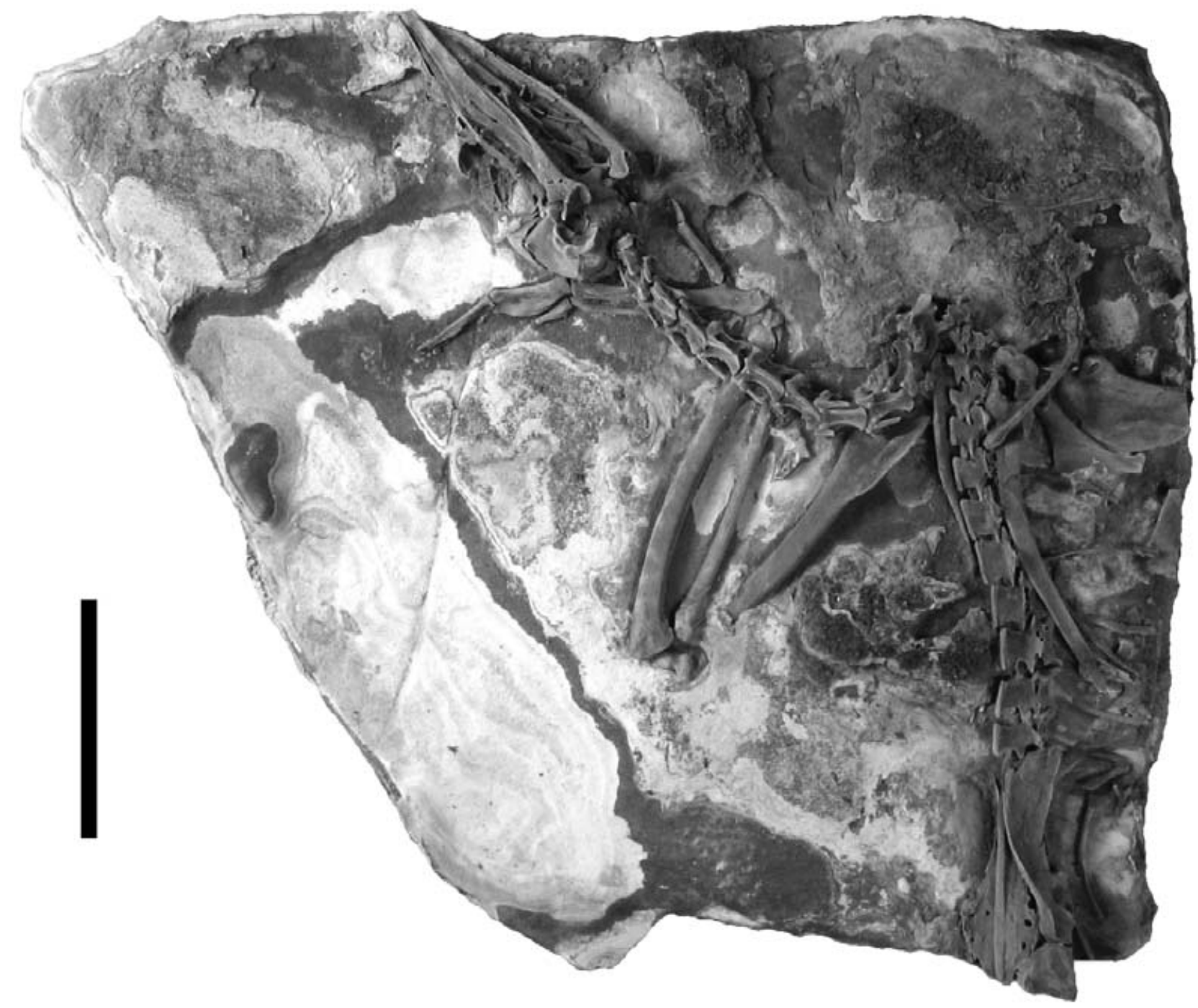

Fig. 4. Partial skeleton (MGUH 26770) referred to the lithornithid Lithornis vulturinus by Leonard et al. (2005). Preserved as a threedimensional, articulated skeleton. Scale bar $=5.0 \mathrm{~cm}$.

and 'waterbirds') out towards the tips [see Cracraft et al. (2004) and Edwards et al. (2005) for recent discussions of the avian tree of life or 'ATOL']. Recently, Mayr (2005) presented a synopsis of the European Eocene fossil record, focussed on birds other than those from the Fur Formation, alongside taxonomic notes.

\section{(a) Palaeognathae, Galloanserae, shorebirds and 'waterbirds'}

At least the Palaeognathae and Galloanserae have long been considered monophyletic, two of the earliest divergences within the neornithine tree (Fig. 1). Some of the largest avian remains collected to date from the Fur Formation belong to the extinct palaeognath group Lithornithiformes (sensu Houde, 1988; Leonard, Dyke \& van Tuinen, 2005). Current phylogenetic consensus suggests that palaeognathous birds are the first divergence amongst modern birds (the sistergroup of all other neognathous birds; Fig. 1); the extant representatives of this clade are the flightless ratites (i.e. ostriches, emus, cassowaries, kiwis and rheas; del Hoyo, Elliot \& Sargatal, 1992), along with the flying Tinamidae (i.e. tinamous; del Hoyo et al., 1992). Lithornithiformes were flying palaeognaths that have been discovered as a clade (i.e. not paraphyletic as suggested by Houde, 1988) in recent phylogenetic studies close to the divergence of ratites, more derived than tinamous (Leonard et al., 2005). Initially described as neognathous birds (Owen, 1841; Harrison \& Walker, 1977), Lithornithiformes have to date been reported from the Fur Formation, the London Clay Formation and from the Paleogene of North America (Houde, 1988; Kristoffersen, 1999, 2002 b; Leonard et al., 2005).

From within the Fur Formation, a diverse assemblage representative of this extinct 'order' has been collected and described. Kristoffersen (1999, 2002 b) described two partial specimens and an isolated humerus, while recently, Leonard et al. (2005) described an almost complete, articulated skeleton of Lithornis vulturinus (MGUH 26770; Fig. 4) that has 
allowed clear diagnosis of this clade for the first time. Lately, new and associated material has also emerged. Remains of lithornithiform birds are also known from the contemporary Olst Formation; Houde (1988) referred a partial humerus to Lithornis cf. nasi (mistakenly described as originating from within the 'plastic clay'; Kristoffersen, 2002b).

The Fur specimen of Lithornis vulturinus (MGUH 26770) is the best preserved representative of this extinct group yet known and has a remarkable three-dimensional skull associated to its postcranial skeleton (Fig. 4). New anatomical information afforded by this fossil shows that a number of cranial characters previously considered diagnostic for ratites may in fact be primitive among palaeognaths, including tinamous (Leonard et al., 2005).

Moving up the tree into the neognathous birds (Fig. 1), the next divergence within Neornithes comprises the traditional 'orders' Galliformes ('landfowl'; pheasants, quail, peafowl and relatives) and Anseriformes ('waterfowl'; screamers, ducks and geese), often collectively termed Galloanserae. These two orders have long been placed together as a single clade (see Cracraft et al., 2004), although one recent poorly taxon-sampled data set appears to refute this (Bourdon, 2005). In any case, no specimens pertaining to Anseriformes have yet been described from the Fur Formation, while two specimens are presently referred to Galliformes. Kristoffersen (2002 b) tentatively assigned two imprints of articulated leg bones to the extinct galliform families Gallinuloididae and Paraortygidae (see Mayr, 2005). Although incomplete, these Danish records are tantalising because any new fossil material is important; the phylogenetic placement of these and other fossil galliform taxa with respect to the extant crown-group remains in question. The Fur Formation galliforms demonstrate that these birds were common in the Lower Eocene; they are present in all of the known fossil-bird-bearing deposits of this age (Dyke \& van Tuinen, 2004; Mayr, 2005). By the time of the earliest Paleogene, Galliformes are well-represented both in Europe and North America. Mayr (2005, p. 3) has argued that all 'sufficiently well-preserved' pre-Oligocene taxa that have been described to date are members of the 'stem', rather than the 'crown-group' of this clade (see Mayr \& Weidig, 2004). What Mayr (2005) implies, presumably, is that no fossil members of the three widely recognised extant clades of Galliformes - megapodes, cracids and 'phasianoids' (del Hoyo et al., 1992; Dyke, Gulas \& Crowe, 2003; Mayr \& Weidig, 2004) - have been described from either the Palaeocene or Eocene. Some cladistic analyses including the Lower Eocene fossil Gallinuloides are contrary to this conclusion; clearly, more work remains to be done in this area of fossil neornithine phylogenetics (Dyke, 2003).

Outside of these early neornithine divergences, palaeognaths and Galloanserae, the phylogenetic relationships of higher taxa are less well understood. Indeed, quite a number of the traditionally recognised avian 'orders' are now considered paraphyletic, or at least are of uncertain monophyly, on the basis of molecular sequence comparisons (e.g. Cracraft et al., 2004) or reasonably comprehensive morphological data sets (e.g. Mayr \& Clarke, 2003; but see Livezey, 1998). One of the larger of these 'wastebasket' orders is Gruiformes, a group that has traditionally included the rails, cranes and bustards (Gill, 1995). A substantial number of Paleogene fossil taxa have over the years been referred to this clade (Olson, 1985; Mayr, 2005). Several specimens from the Fur Formation are putatively 'gruiform', but will require a good deal of further study. For example, Hoch (1975) assigned a partially prepared skull imbedded in a calcareous concretion to Rallidae. This little specimen has now been prepared more completely, showing that it is almost complete, although further study will be required to determine its phylogenetic affinities. A second Fur Formation specimen was compared with extant Galliformes by Hoch (1997), who did not comment further on its 'ordinal' affinities; this specimen was later referred to the extinct Messelornithidae by Kristoffersen $(2002 b)$. Although currently subject to revision, Fur Formation fossil material joins certain representatives of Messelornithidae known from other sediments of Palaeocene to Lower Oligocene age in Europe (Hesse, 1990; Mourer-Chauviré, 1995). Often associated with Gruiformes in the past, the phylogenetic affinities of these birds remain debated (see Livezey, 1998; Mayr, 2004 b).

Representatives of the living groups of 'waterbirds', the 'Pelecaniformes' (pelicans and cormorants) are relatively diverse in Paleogene deposits worldwide. In extant faunas these birds also enjoy an almost world-wide distribution (Gill, 1995). Although the phylogenetic relationships of these birds are in dire need of systematic revision (even the monophyly of 'Pelecaniformes' is currently questioned), a number of fossil taxa showing anatomical similarities to other known fossil representatives are present in the Fur Formation collections. Kristoffersen (2002b) noted the presence of a supposed pelecaniform from this deposit on the basis of two specimens. One of these fossils comprises a nearly complete post-pelvic skeleton (including the legs three-dimensionally preserved in calcareous concretions), and the other is a tibiotarsus-fibula complex preserved as an imprint in diatomite. Most interestingly, this fossil material may pertain to the only currently known ocean-going (i.e. fully marine) bird collected to date from the Fur Formation.

Charadriiform birds comprise one of the other traditional avian 'orders' that is likely monophyletic, supported by morphological (Mayr, 2000) and molecular data (Ericson et al., 2002; Paton et al., 2003). This clade includes a large number of familiar shorebirds and wading birds that presently enjoy a world-wide distribution, occurring on all continents around the world (e.g. Monroe \& Sibley, 1993). Although relatively rare in the European Paleogene (Mayr, 2005), well-preserved fossil Charadriiformes have been described from the Eocene (e.g. Mayr, 2000). The presence of these birds has been noted on the basis of much less wellpreserved fossil material from Tertiary localities around the world (Olson, 1985; Boles, 1999; Hou \& Ericson, 2002), including the Fur Formation. Kristoffersen (2002b) described a small, articulated specimen, which has been touted as a new shorebird taxon (see Dyke \& van Tuinen, 2004). Whatever the final outcome of phylogenetic analyses including this new fossil material, this Danish specimen is easily the best preserved representative of this clade from the Lower Eocene; with the exception of its forelimbs and left 
leg, this fossil is completely articulated and even has its skull preserved in three dimensions. Other specimens known from the lowermost Eocene are fragmentary, comprising single elements (e.g. Harrison \& Walker, 1977). Thus the Fur Formation material presents our best chance yet to resolve phylogenetic relationships within this clade while also including fossils. Charadriiforms are one of the groups of Neornithes for which dating divergences has generated controversy. Because these birds have a putative Cretaceous record on the basis of fossil fragments (Olson \& Parris, 1987; Hope, 2002), well-represented early Paleogene material can help to time the early divergences within this clade and to test estimates for their evolution founded on molecular sequence comparisons (e.g. Cooper \& Penny, 1997).

\section{(b) Parrots and 'higher land birds'}

Although this second of our informal subdivisions is used for clarity in this paper, at least some of the traditional 'orders' mentioned appear to have some morphological support (Mayr \& Clarke, 2003; Mayr, Manegold \& Johansson, 2003). The term 'higher land birds', for example, was first used by Olson (1985) to denote a grouping of modern avian taxa roughly equivalent to an older classification dating from the work of Garrod (1874); 'Caprimulgiformes' (nightjars and relatives), Apodiformes (swifts and hummingbirds), Coliiformes (mousebirds), Trogoniformes (trogons), Coraciiformes (rollers and allies), Strigiformes (owls), Piciformes (woodpeckers and allies) and Passeriformes (perching songbirds). Of these groups, Passeriformes are by far the most abundant in modern avifaunas, comprising some 90 per cent of extant bird species (Gill, 1995). With the exception of Piciformes, 'higher land birds' and Psittaciformes (parrots) at least are well-represented in the Fur Formation.

Psittaciformes comprise a well-known group of tropical and subtropical modern birds that are certainly monophyletic on the basis of their lower leg morphology. Parrots have a unique zygodactyl perching foot morphology. In recent years the fossil record of these birds has been well described; several taxa of Psittaciformes are known from the Eocene of Europe (Mayr \& Daniels, 1998; Dyke \& Cooper, 2000; Dyke, $2001 a$; Mayr, 2002a). Of known taxa of parrots, morphological treatments (Mayr, 2002a) have considered members of Pseudasturidae to be a 'stemgroup' or 'plesion' with respect to the extant crown-group. Pseudasturid birds were first described by Mayr (1998a) who initially classified the family as incertae sedis. LowerMiddle Eocene taxa considered as parrots have been described from the London Clay (Harrison, 1982; Dyke \& Cooper, 2000) and Messel (Mayr \& Daniels, 1998). Mayr (2001) critiqued Dyke \& Cooper (2000) for their description of one London Clay specimen as a psittaciform, referring it instead to Pseudasturidae. Mayr (2002a) considered Pseudasturidae itself to be psittaciform, thus returning much Lower Eocene fossil material to its original position (see Dyke \& Cooper, 2000). One relatively large, threedimensionally preserved humerus from the Fur Formation was considered psittaciform by Kristoffersen (2002b) and probably represents the earliest known crown-group member of the clade. Kristoffersen $(2002 b)$ also tentatively referred a left humerus to the genus Pseudastur (Pseudasturidae). Together with material from the Eocene London Clay (Dyke \& Cooper, 2000; Dyke 2001a), these specimens represent some of the earliest records of psittaciform birds. The mousebirds, Coliiformes, are another clade of modern birds that have an abundant Eocene fossil record (Dyke \& van Tuinen, 2004; Mayr, 2005), although restricted to just six species today. These birds are well-represented in the Fur Formation, from which two distinct forms have been described (Fig. 5). The first European record of the sandcoleidid Chascacolius, an isolated forelimb, was described by Dyke et al. (2004) (Fig. 5A). This taxon was originally described from the Paleocene and Lower Eocene of North America (Houde \& Olson, 1992). Another genus already documented in Europe, Eoglaucidium (Kristoffersen, 2002 b) (Fig. 5B), is also known from the Middle Eocene of Germany (Mayr \& Peters, 1998). Coliiforms are an interesting group of birds, given their abundant fossil record that starts in the Paleogene. Mayr (2005) reviewed the phylogenetic relationships within this clade, noting that the Upper Eocene and Lower Oligocene taxa Primocolius and Oligocolius form a sister clade to extant mousebirds (see Fig. 4 in Mayr, 2005) on the basis of their carpometacarpus morphology (Fig. 5C) (see also Mayr \& Peters, 1998; Dyke \& Waterhouse, 2000). This hypothesis was first presented in detail, based on a phylogenetic analysis, by Mayr \& MourerChauviré (2004, their Fig. 4) who listed six characters of the toes, legs and forelimbs interpreted as synapomorphies of certain Paleogene taxa and extant mousebirds. Although the Fur Formation mousebird material is certainly basal with respect to the crown taxa and will be added to forthcoming phylogenetic analyses (G.J. Dyke, in preparation), existing systematic arrangements for these birds directly contravene the hypothesis of Mayr (2005, p. 1) that 'no crown-group members of modern "families" are known from preOligocene deposits in Europe, or anywhere else'. This is an issue that will be returned to later in this review.

The remaining diversity of 'higher land birds' from the Fur Formation is indicative of smaller birds; small owls (Strigiformes), swifts (Apodiformes), nightjars (Caprimulgiformes), trogons (Trogoniformes) and their relatives, including several enigmatic extinct groups. The putative presence of owls in the Fur fauna is based on a single threedimensionally preserved sternum (Fig. 6A), provisionally assigned to the order Strigiformes by Kristoffersen (2002 b). We draw attention to this specimen here; its affinities will clearly require further work. It is worth noting that in general the fossil record of owls is good, extending back at least into the Paleocene (see Mayr, 2005). This clade of modern birds is considered to comprise two extant 'families' (Strigidae, true owls, and Tytonidae, barn owls). Owls have a world-wide distribution in modern avifaunas (Gill, 1995).

Apodiformes, the clade that comprises swifts and hummingbirds, have a diverse fossil record that extends back into the Paleocene-Eocene in Europe and North America. A putative stem-group taxon (sensu Mayr, 2005) with respect to extant swifts (Scaniacypselus; Apodidae) was first described from the Røsnæs Clay Formation of Denmark (Harrison, 1984). The Røsnæs Clay Formation is 


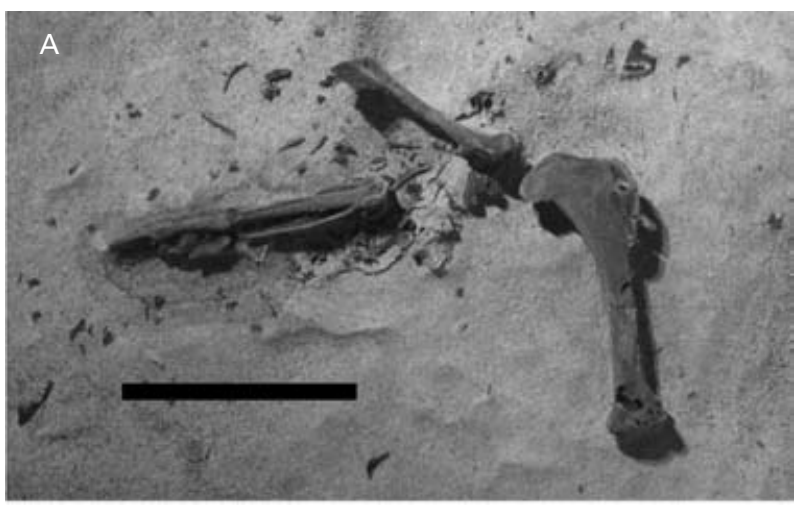

B

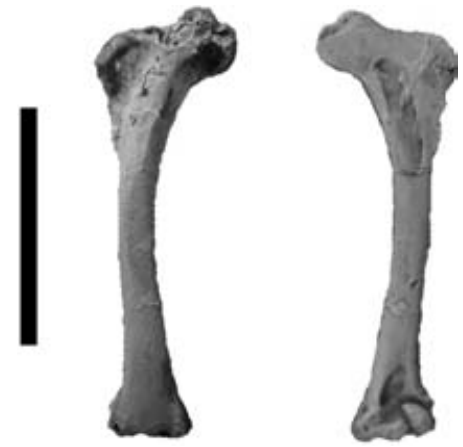

C

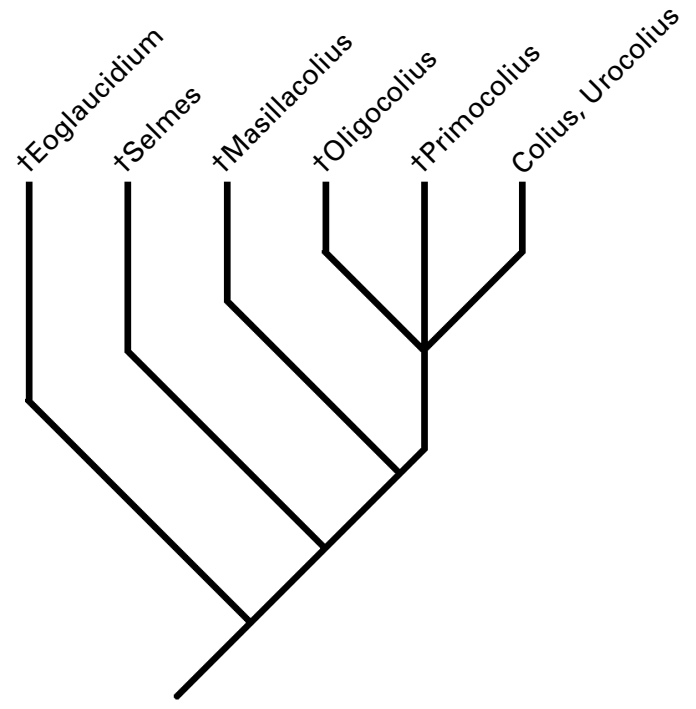

Fig. 5. Mousebirds from Denmark and their phylogenetic relationships. (A) Chascacolius cf. oscitans: isolated forelimb (MGUH 26731; Dyke et al., 2004). (B) ?Eoglaucidium sp.: left humerus in caudal and cranial view (MGUH.VP 1282; Kristoffersen, 2002a). (C) Simplified tree for mousebirds (after Fig. 4 in Mayr, 2005). $\dagger$ indicates extinct groups. Scale bar $=2.0 \mathrm{~cm}$.
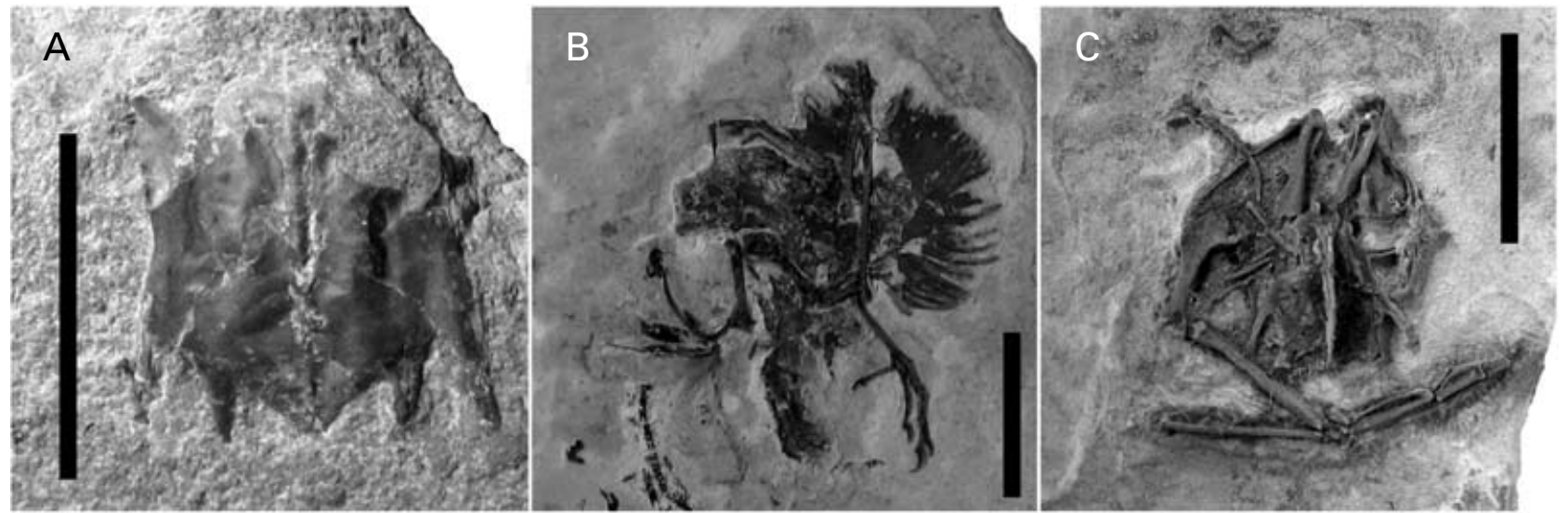

Fig. 6. Fossil remains of various small birds from the Eocene Fur Formation. (A) Sternum (MGUH DK 8) referred to Strigiformes (owls) by Kristoffersen $(2002$ b). (B, C) Two specimens referred to the fossil apodiform Eocypselus vincenti by Dyke et al. (2004). (B) MGUH 26729. (C) MGUH 26730. Scale bars $=2.0 \mathrm{~cm}$.

now considered Lower Eocene (Ypresian) in age (not Middle Eocene, pace Harrison, 1984). Similar forms are also represented in the Lower Eocene London Clay Formation and the French late Oligocene (Mourer-Chauviré, Berthet \& Hugueney, 2004). However, interpretation of these forms as 'stem-group' taxa (Mayr, 2005) is a matter of 
phylogenetic scale (see below). Most recently, Dyke et al. (2004) referred two partial skeletons from the Fur Formation to the apodiform Eocypselus vincenti (see Fig. 5 in Mayr, 2005) (Fig. 6B, G). This taxon was originally described as an early representative of the extant tree or crested swifts (Hemiprocnidae) (Harrison, 1984), but is now considered to be outside crown-group Apodiformes (Mayr, 2003; Dyke et al., 2004). Most intriguingly, the known Lower Eocene Danish material brackets almost the entire systematic range of known fossil swifts and the fossils from the Fur Formation demonstrate that the bulk of early apodiform radiation had already taken place by the time of the Lower Eocene, 58 MYA (see Fig. 5 in Mayr, 2005). No fossil hummingbirds are yet known from the Danish Lower Eocene, although the oldest confirmed fossil records of these birds are from Paleogene deposits of similar age in Europe (Mayr, 2003, $2004 a)$.

One particularly unique fossil known from the Fur Formation is the oldest recognised record of the enigmatic avian clade of trogons (Trogoniformes). These birds are characterised by the presence of a specialised heterodactyl foot (where the second of the four toes is permanently directed backwards). Kristoffersen (2002a) described an isolated neurocranium of Septentrogon madseni from the Fur Formation, which is roughly the same age as an isolated tarsometatarsus from the London Clay (see Mayr, 1999). Several other isolated specimens are also known from the Fur Formation (Kristoffersen, 2002b). Because the fossil record of these birds is so sparse (see Mayr, 2005), any and all new material presents an important research resource.

Although boasting a well-diversified Paleogene fossil record, the traditional avian 'order' Caprimulgiformes is now considered paraphyletic (Mayr, $2002 b$; Mayr et al., 2003), grouped alongside swifts and hummingbirds in a single clade ('Cypselomorphae'; see Mayr et al., 2003) that comprises the aerial insectivores. Generally accepted, the order 'Caprimulgiformes' is subdivided into Nyctibiidae (potoos) and Caprimulgidae (nightjars); neither of these groups is known with certainty from the Danish Fur Formation, although Kristoffersen (2002b) tentatively referred an isolated tarsometatarsus and phalanges to the order Caprimulgiformes based on their overall morphological similarity.

Coraciiformes is the taxon comprising rollers, groundrollers, kingfishers and hoopoes and is another example of a 'higher land bird' grouping with uncertain morphological support. Although much fossil material referred to this group is known from other Paleogene-aged deposits in Europe and around the world, the bulk of the coraciiform fossil record that is well-preserved enough to be included within phylogenetic analyses comes from the German Middle Eocene deposit of Messel (Mayr, 1998b). Coraciiform specimens from the London Clay available for study (i.e. those that are not in private collections) consist of isolated, often fragmentary, single bones (Dyke, 2001 a) and even those from Messel are not as well-preserved in three dimensions as Fur Formation specimens, of which several are known. Hoch \& Pedersen (1983) referred a remarkable specimen from the upper part of the formation to the group, consisting of an imprint of an almost complete skeleton that preserves imprints of long tail feathers and Kristoffersen (2002b) referred an isolated tarsometatarsus with associated digits. Furthermore, a completely articulated and as yet undescribed specimen from the formation appears to belong to this clade.

Finally, perhaps the most intriguing avian fossil material known to date from the Fur Formation is records of small primoscenid birds (Kristoffersen, 2002b). These are small zygodactyl birds, with perching feet orientated in a similar way to parrots, with two toes forward and two pointed back, well-known from the European Paleogene (Mayr, 1998 b). Primoscenidae were first described as Passeriformes (Harrison \& Walker, 1977; see also Olson, 1985) and have been considered as either closely related to the songbird clade (Harrison \& Walker, 1977) or to Piciformes (Mayr, 1998 b), but the precise phylogenetic relationships of these enigmatic small perching birds remain unknown (Mayr, 2005). Piciformes is the clade that includes extant birds like jacamars and woodpeckers, considered the sistergroup to Passeriformes (Mayr et al., 2003) and to date not known from the Fur Formation. Kristoffersen (2002b) referred a three-dimensionally preserved postcranial skeleton to the Primoscenidae and another largely complete specimen, preserved as an imprint in diatomite, has recently been acquired by the Geological Museum in Copenhagen.

\section{ADDRESSING THE EOGENE AVIAN RADIATION}

\section{(1) Climate change}

It has been argued elsewhere that the Paleogene avifaunas currently known from around the world are similar, at least in terms of their broad-scale taxonomic compositions (Houde \& Olson, 1992; Blondel \& Mourer-Chauviré, 1998; Mayr, 2005). This is to be expected given the phylogenetic scale at which such comparisons can usefully be made; familial and ordinal level, for example (Mayr, 2005). As has been argued elsewhere (Blondel \& Mourer-Chauviré, 1998) climate change was surely the single most significant brake impacting on the early radiation of modern birds. We expect that, in addition to the K-P extinction event, climate change throughout the Eocene would have acted as the second major factor driving the evolution of modern birds at this time. Blondel \& Mourer-Chauviré (1998), for example, listed 44 family-level groups identified in the fossil record by the end of the Eocene in Europe, half of which (22) are still represented in modern avifaunas. Although the known fossil record is not yet calibrated temporally to the scale required to test specific hypotheses about lineage dynamics in response to climatic fluctuations, it is nevertheless possible to pick out overall trends and to comment on lineage evolution. We can do this because deposits that preserve the abundant remains of fossil modern birds, such as Messel, the London Clay and Fur formations, include a diversity of tropical non-passerine taxa such as Coraciiformes, primoscenids and Psittaciformes. Unless these deposits merely record local climatic optima, these kinds of birds are likely to have been widespread across the northern hemisphere at the 
time. For most of the Paleogene there were few large climatic excursions in Europe (Blondel \& Mourer-Chauviré, 1998); temperatures were subtropical and European forests extended as far north as Greenland and northern Canada. It is not surprising that the avian faunas across the northern hemisphere were also similar at this time.

The fossils known from this time interval demonstrate that the bulk of the modern 'orders' was already present by the time of the Lower Eocene (e.g. see Table 2 in Mayr, 2005). Studies of specific lineage responses to the climate change are somewhat hampered by the fact that while some groups have a good fossil record throughout the period, most have a more patchy temporal distribution. Assuming that present knowledge is reasonably adequate and accounting for future discoveries and re-descriptions of taxa, the study of a few lineages can reveal some patterns of extinction and evolution. For example, the extinct flying relatives of ratites, Lithornithiformes, are well-known and apparently abundant in Paleocene and Lower Eocene marine and terrestrial deposits from both Europe and North America, but despite years of collecting none are known from Middle Eocene or younger deposits. The apparently widespread demise of this once diverse and important group in the northern hemisphere (Houde, 1988) might be related to climatic deterioration, which commenced during the Middle Eocene.

Another lineage with a previously widespread northern hemisphere distribution which also disappeared are the giant gastornithid 'terror-cranes', now considered to be Anseriformes (Mayr, 2005). The 'family' is present in deposits from the Paleocene to the Lower Eocene in Europe and North America (Prothero, 1994a) and lingers on until the lower Middle Eocene in Europe (Mayr, 2005). Gastornithids are hypothesised to have been carnivorous (Mayr, 2005), and their staggered extinction pattern of North America first and Europe later probably reflects that of their mammalian prey, as well as a preference for a more closed forest habitat. Replacement of subtropical evergreens by more deciduous floras and more open vegetation and their associated mammal fauna during the Middle Eocene appears to have occurred earlier and more severely in North America than in Europe (Prothero, 1994a).

Based on the currently available fossil record, it is also possible to discern patterns of replacement within some relatively well-studied orders with an extensive fossil record. For example, within Galliformes ('landfowl'), Gallinuloididae and Quercymegapodiidae disappear at the end of the Middle and Upper Eocene, respectively (see Table 2 in Mayr, 2005). They are replaced by the Paraortygidae in the Upper Eocene (Mayr, 2005), while the Phasianidae (pheasants and relatives) appear in the Lower Oligocene (Mourer-Chauviré, 1992). It has been previously hypothesised that the Phasianidae may have superseded or displaced more primitive families (Mourer-Chauviré, 1992). Phasianids have a large and well-developed crop, reflected by the morphology of the sternum (breastbone) and furcula (wishbone) of these birds (Stegmann, 1964). Comparison of the morphology of the phasianid sternum and furcula with that of the extinct groups indicates that the latter had a less efficient crop and might have been replaced by the phasianoids, which were more efficient seed-eaters as the environment became drier and more open. This scenario is nicely mirrored by the concurrent replacement of some endemic European mammal groups by Asian rodents, also better adapted to seed-eating (Prothero, $1994 a, b)$.

\section{(2) A question of phylogenetic scale}

Although the pattern of the evolutionary radiation of modern birds (Neornithes) has been debated based on morphological and molecular data-sets, evidence based on the placement of Paleogene fossil taxa has only recently been introduced (Cracraft, 2001; Mayr, 2005). Some studies had used Paleogene fossils either to calibrate molecular clocks (e.g. Cooper \& Penny, 1997) or to formulate completeness tests based on the fossil record (e.g. Bleiweiss, 1998), but did not take into account the questionable phylogenetic placements of the taxa in question. Dyke $(2001 b)$ utilised a number of independent phylogenetic hypotheses to predict that while some of the earliest diverging clades of Neornithes were present prior to the K-P extinction horizon (i.e., Palaeognathae, Galliformes and Anseriformes), the bulk of the remainder of the modern avian radiation took place in the earliest Paleogene. This has been developed into a hypothesis similar to that formulated by Feduccia (1995, 2003): an explosive radiation of modern birds in the aftermath of the K-P extinction, and is corroborated by the described (albeit fragmentary) Cretaceous records (Hope, 2002; Clarke et al., 2005). The only well-represented neornithine bird from the Mesozoic thus far described is the anseriform Vegavis iaai (Clarke et al., 2005), from the Cretaceous of Antarctica. However, phylogenetic hypotheses that include the known Cretaceous and Paleogene fossil record of Neornithes remain thin on the ground. Many of the phylogenetic analyses that have been conducted, for example including the anseriforms Vegavis, Presbyornis and Anatalavis (Livezey, 1997; Dyke, 2001 a; Clarke et al., 2005), place these taxa close to or within the crown-group of these clades, alongside extant taxa. A similar result was recovered by Livezey (1998) in his analysis of gruiform interrelationships, which included the Messel fossil Messelornis. The cladistic hypothesis suggests placement of Messelornis within a clade also comprising the extant Eurypyga (sunbittern), Rhynochetos (kagu) and the extinct Aptornis (adzebill) (Livezey, 1998). These four taxa are hypothesised to comprise the clade Eurypygae, nested well within crown-group gruiforms, with a number of lineages leading to extant taxa occurring in more basal positions (but crown-group gruiforms nevertheless) within the phylogeny (e.g. hemipodes, buttonquails and mesites).

In the face of much contradictory phylogenetic evidence drawn from fossil taxa, Mayr (2005, p. 1) argued that 'no crown-group members of modern "families" are known from the Eocene or older deposits in Europe or anywhere else' and that 'the diversification of the "crown-groups" within modern avian "families" did not take place before the Oligocene, irrespective of the relative placement of these taxa within Neornithes'. Discussion of this hypothesis is a matter of phylogenetic scale, requiring clear characterbased diagnoses of extant avian 'families' as nested clades 
within clades. As yet, the phylogenetic resolution to test this hypothesis in the context of modern birds simply does not exist. To argue confidently that there were no crowngroup representatives of modern 'families' present in the Paleogene, one would require a genus-level tree for the clade in question into which fossil taxa can be introduced. There are currently few examples of modern avian clades within which this kind of resolution has been achieved by use of morphological characters, while analyses of fossils founded on the few hypotheses that do exist, Galliformes, Anseriformes and Gruiformes, contradict Mayr's (2005) hypothesis. The phylogenetic relationships of fossil taxa of galliforms remain controversial (Dyke, 2003; Mayr \& Weidig, 2004), but those placed within Anseriformes do not. Most striking of all, in Clarke et al.'s (2005) morphological phylogenetic analysis, the Cretaceous Vegavis was placed in a more crown-ward phylogenetic position than extant screamers Chauna and Anhima, Magpie-Goose Anseranas and the Paleogene fossil Anatalavis. This analysis of anseriform inter-relationships corroborates the earlier hypotheses of Livezey (1997) for the fossil Presbyornis and Dyke (2001 b) for Anatalavis. For Mayr's (2005) hypothesis to be correct, i.e. the crown-group 'families' of modern birds did not radiate until the Oligocene, Clarke et al.'s (2005) robust phylogenetic hypothesis for anseriforms is either incorrect or the extant screamers and Magpie-Goose are no longer to be considered members of extant anseriform 'families'.

What we do know is that well-known fossil modern birds from deposits of early Paleogene age provide a window on the extent of the evolutionary radiation of the group at the time and that the placement of taxa in, or close to, crowngroup positions implies the appearance of these 'orders' at earlier times than the early Paleogene. The inclusion of fossils within phylogenies allows minimum-age estimates to be placed on the divergence times of internal nodes. As many of the Fur Formation specimens are well-enough preserved to be included within new and existing phylogenetic analyses, they can be used to address the timing and extent of the modern avian radiation prior to, and into, the Paleogene.

\section{GONGLUSIONS}

(1) The fossil record of modern birds, the abundance and diversification of taxa, is linked to changes in climate throughout the Eocene. Despite the spatiotemporal shortcomings of the known avian fossil record of the epoch, some lineage dynamics in response to climatic fluctuations can be discerned. The extinction at the beginning of the Middle Eocene of the Lithornithiformes, who appear previously to have been a diverse and abundant group during the Paleocene and Lower Eocene, could be related to climatic deterioration in North America and Europe. Likewise the extinction of the giant, carnivorous Gastornithidae in the lower Middle Eocene might reflect changes in prey and habitat brought about by climatic change. Within one lineage, the Galliformes, the replacement of archaic families by phasianoids during the
Oligocene probably reflects better adaptation to food processing in new, drier habitats, again occasioned by overall climatic deterioration.

(2) Although debates regarding the origination of both modern birds as a whole (i.e. early Cretaceous, late Cretaceous, early Paleogene) and the crown-group modern 'families' persist, it is clear that the Paleocene and Lower Eocene was a time of great avian diversification, perhaps as a result of favourable global climatic conditions. In Europe, the combination of slowly deteriorating climatic conditions and persisting close proximity to the North American continent from the Middle Eocene onwards, might have slowed the evolutionary rate, as the faunas did not markedly differentiate until the Oligocene when seasonal climates at mid-latitudes began to prevail around the world. At this time, in combination with a more marked isolation of Europe from North America, it is suggested that faunas on both sides of the Atlantic began to differentiate and diversify anew (Blondel \& Mourer-Chauviré, 1998). This then may be the 'origin of crown-group family-level' clades to which Mayr (2005) refers.

(3) Because little sampling effort in deposits of this age (and older) has taken place in the southern hemisphere, hypotheses suggesting that some, or all, of the modern avian radiation may have taken place outside of the well-sampled northern hemisphere regions cannot readily be tested at present.

(4) The goal of current research must be the continued development of an accurate evolutionary timescale for modern birds, or at least one that can accurately combine the use of fossils with advances in molecular methods. The discovery and description of well-preserved fossil taxa is not enough. Much work remains to address the relationships of the existing neornithine fossil record within the context of morphological and molecular phylogenetic analyses for the extant clades of birds. On one hand, the quality of the Paleogene avian fossil record of modern birds is well known; the fossil record continues to reveal an abundance of taxa, some of them, like the Fur Formation birds, exceptionally well preserved and clearly highly anatomically informative. On the other hand, the importance of the Paleogene fossil record cannot be understated. There is little question that many of these fossils will prove relevant in testing the validity of many of the traditional higher taxa of birds. An integrated approach to the relationships of Neornithes, including information from the morphology of fossils and extant birds, as well as their molecular make-up will be required to resolve the timing of evolutionary diversification of this major vertebrate group.

(5) Data thus far available on the extent of the neornithine fossil record by the earliest Paleogene does not require the appearance of all the major modern clades prior to the K-P boundary. Earlier diverging clades within Neornithes were clearly present in the Cretaceous as evidenced directly by new fossil material alongside phylogenetically constrained Lower Eocene taxa. A later Oligocene radiation of some clades within Neoaves, other than Passeriformes, is not supported by available fossil data. Finally, we would argue that the fossil record of modern birds is not poor, as a large number of specimens well 
enough preserved to be used in phylogenetic analyses are known from the early Tertiary, in contrast to the described Mesozoic records. Although much further work is required to elucidate the relationships of extant taxa on the basis of osteological characters and then to combine fossils within these analyses, the pattern of and factors influencing the evolutionary radiation of this major vertebrate group is beginning to emerge.

\section{AGKNOWLEDGEMENTS}

Ongoing work on Danish fossil birds would not have been possible without the support of Anette Kristoffersen; we thank her for her help, understanding and expertise. Access to fossils in Copenhagen was facilitated by Gilles Cuny and Niels Bonde. We also thank Sara Bertelli, Luis Chiappe, Gilles Cuny, Dave Harper and Sten Lennart Jakobsen for their continued help and advice with this project. Our ongoing work on the Fur Formation fossil birds is funded by the Irish Research Council for Science Engineering and Technology (IRCSET) and the National Science Foundation, USA (NSF DEB-0454856). We are very grateful for comments on this paper made by Cornelis Hazevoet and Tim Crowe; three further anonymous referees contributed greatly to improve the clarity of the arguments presented here.

\section{REFERENGES}

Bains, S., Corfield, R. M. \& Norris, R. D. (1999). Mechanisms of climate warming at the end of the Paleocene. Science $\mathbf{2 8 5}$ 724-727.

Berggren, W.A. (1992). Role of ocean gateways in climatic change. In Climate in Earth History (eds. W. Berger and J. C. Crowell), pp. 118-285. National Academy of Sciences, Washington DC.

Beyer, C., Heilmann-Clausen, C. \& Abrahamsen, N. (2001). Magnetostratigraphy of the Upper Paleocene-Lower Eocene deposits in Denmark. Newsletter on Stratigraphy 39, 1-19.

BLeIweiss, R. (1998). Fossil gap analysis supports early Tertiary origin of trophically diverse avian orders. Geology 26, 323-326.

Blondel, J. \& Mourer-Chauviré, C. (1998). Evolution and history of the western Palaearctic avifauna. Trends in Ecology and Evolution 13, 488-492.

Boles, W. E. (1999). Early Eocene shorebirds (Aves: Charadriiformes) from the Tingamurra Local Fauna, Murgon, Queensland, Australia. Records of the Western Australian Museum Supplement 57, 229-238.

Bonde, N. (1987). Moler-its Origin and its Fossils Especially Fishes. Skamol, Nykøbing Mors, Denmark.

Boulter, M. C. (1984). Palaeobotanical evidence for land-surface temperatures in the European Paleogene. In Fossils and Climate (ed. P.J. Brenchley), pp. 35-47. John Wiley and Sons, Chichester.

Bourdon, E. (2005). Osteological evidence for sister group relationship between pseudo-toothed birds (Aves: Odontopterygiformes) and waterfowls (Anseriformes). Naturwissenschaften 92, 586-591.

Chambers, L. M., Pringle, M., Fitton, G., Larsen, L. M., Pedersen, A. K. \& Parrish, R. (2003). Recalibration of the Palaeocene-Eocene boundary (P-E) using high precision $\mathrm{U}-\mathrm{Pb}$ and Ar-Ar isotopic dating. In Abstract, EGS-AGU-EUG foint Assembly, Nice, 6th-11th April 2003.

Chiappe, L. M. (1995). The first 85 million years of avian evolution. Nature 378, 349-355.

Chiappe, L. M. \& Dyke, G. J. (2002). The Mesozoic radiation of birds. Annual Reviews of Ecology and Systematics 33, 91-124.

Chiappe, L. M. \& Witmer, L. M. (2002). Mesozoic Birds. Above the Heads of Dinosaurs. University of California Press, Berkeley.

Clarke, J. A., Tambussi, C. P., Noriega, J. I., Erickson, G. M. \& Ketcham, R. A. (2005). Definitive fossil evidence for the extant avian radiation in the Cretaceous. Nature 433, 305-308.

Collinson, M. E. (1983). Palaeofloristic assemblages and palaeoecology of the lower Oligocene Bembridge Marls, Hamstead Ledge, Isle of Wright. Botanical Journal of the Linnean Society 86, $177-225$

Collinson, M. E. (1992). Vegetational and floristic changes around the Eocene/Oligocene boundary in western and central Europe. In Eocene-Oligocene Climatic and Biotic Evolution (eds. D. R. Prothero and W. A. Berggren), pp. 437-450. Princeton University Press, Princeton.

Collinson, M. J., Fowler, K. \& Boulter, M. C. (1981). Floristic changes indicate a cooling climate in the Eocene of southern England. Nature 291, 315-317.

Collinson, M. E. \& Hooker, J.J. (1987). Vegetational and mammalian faunal changes in the early Tertiary of southern England. In The Origins of Angiosperms and their Biological Consequences (eds. E. M. Friis, W. G. Chaloner and P. R. Crane), pp. 259-304. Cambridge University Press, Cambridge.

Cooper, A. \& Penny, D. (1997). Mass survival of birds across the Cretaceous-Tertiary boundary: molecular evidence. Science 275, 1109-1113.

Cracraft, J. (2001). Avian evolution, Gondwana biogeography and the Cretaceous-Tertiary mass extinction event. Proceedings of the Royal Society of London, Series B 268, 459-469.

Cracraft, J., Barker, F. K., Braun, M., Harshman, J., Dyke, G. J., Feinstein, J., Stanley, S., Cibois, A., Schikler, P., Beresford, P., García-Moreno, J., Sorenson, M. D., Yuri, T. \& Mindell, D. P. (2004). Phylogenetic relationships among modern birds (Neornithes): towards an avian tree of life. In Reconstructing the Tree of Life (eds. J. Cracraft and M. Donoghue), pp. 468-489. Oxford University Press, Oxford.

Cracraft, J. \& Clarke, J. A. (2001). The basal clades of modern birds. In New Perspectives on the Origin and Early Evolution of Birds (eds. J. Gauthier and L. F. Gall), pp. 143-156. Peabody Museum of Natural History, New Haven.

Crouch, E. M., Heilmann-Glausen, C., Brinkhuis, H., Morgans, H. E. G., Rogers, K. M., Egger, H. \& Schmitz, B. (2001). Global dinoflagellate event associated with the late Paleocene thermal maximum. Geology 29, 315-318.

Del Hoyo, J., Elliot, A. \& Sargatal, J. (1992). Handbook of Birds of the World, Volume 1. Ostrich to Ducks. Lynx Editions, Barcelona.

Dyke, G.J. (2001a). Fossil pseudasturid birds (Aves, Pseudasturidae) from the London Clay. Bulletin of the Natural History of London (Geology Series) 57, 1-4.

Dyke, G. J. (2001 b). The fossil waterfowl (Aves: Anseriformes) from the Eocene of England. American Museum Novitates 3354, 1-15.

Dyke, G.J. (2003). The phylogenetic position of Gallinuloides Eastman (Aves: Galliformes) from the Tertiary of North America. Zootaxa 199, 1-10.

Dyke, G. J. \& Cooper, J. H. (2000). A new psittaciform bird from the London Clay (Lower Eocene) of England. Palaeontology 43, 271-285. 
Dyke, G.J. \& Gulas, B. E. (2002). The fossil galliform bird Paraortygoides from the Lower Eocene of the United Kingdom. American Museum Novitates 3360, 1-14.

Dyke, G. J. \& Van Tuinen, M. (2004). The evolutionary radiation of modern birds (Neornithes): reconciling molecules, morphology and the fossil record. Zoological Fournal of the Linnean Society 141, 153-177.

Dyke, G. J., Gulas, B. J. \& Crowe, T. M. (2003). Suprageneric relationships of galliform birds (Aves, Galliformes): a cladistic analysis of morphological characters. Zoological Fournal of the Linnean Society 137, 227-244.

Dyke, G. J. \& Waterhouse, D. W. (2000). A new fossil mousebird (Aves, Coliiformes) from the London Clay. Fournal für Ornithologie 141, 1-9.

Dyke, G. J., Waterhouse, D. M. \& Kristoffersen, A. V. (2004). Three new fossil landbirds from the early Paleogene of Denmark. Bulletin of the Geological Society of Denmark 51, 47-56.

Edwards, S. V., Kingan, S. B., Calkins, J. D., Balakrishnan, C. N., Jennings, W. B., Swanson, W.J. \& Sorenson, M. D. (2005). Speciation in birds: genes, geography, and sexual selection. Proceedings of the National Academy of Sciences 102, 6550-6557.

Ericson, P. G. P., Envall, I., Irestadt, M. \& Norman, J. A. (2002). Inter-familial relationships of the shorebirds (Aves: Charadriiformes) based on nuclear DNA sequence data. $B M C$ Evolutionary Biology 2003, 3-16.

FaIn, M. G. \& Houde, P. (2004). Parallel radiations in the primary clades of birds. Evolution 58, 2558-2573.

Feduccia, A. (1995). Explosive evolution in Tertiary birds and mammals. Science 267, 637-638.

Feduccia, A. (1999). The Origin and Evolution of Birds. 2nd Edn. Yale University Press, New Haven.

Feduccia, A. (2003). "Big bang" for Tertiary birds? Trends in Ecology and Evolution 18, 172-176.

Fountaine, T. M. R., Benton, M. J., Dyke, G. J. \& Nudds, R. L. (2005). The quality of the fossil record of Mesozoic birds. Proceedings of the Royal Society, Series B 272, 289-294.

Frakes, L. A. \& Kemp, E. M. (1972). Influence of continental positions on early Tertiary climates. Nature $\mathbf{2 4 0}, 97-100$.

Garrod, A. H. (1874). On certain muscles of birds and on their value in classification. Part II. Proceedings of the Zoological Society of London 1874, 111-123.

GILL, F. B. (1995). Ormithology. 2nd Edn. W.H. Freeman and Company, New York.

Gingerich, P. (2003). Mammalian responses to climate change at the Paleocene-Eocene boundary: polecat bench records in the northern Bighorn Basin, Wyoming. In Causes and Consequences of Globally Warm Climates in the Early Paleogene (eds. S. L. Wing, P. D. Gingerich, B. Schmitz and E. Thomas), pp. 463-478. Geological Society of America Special Paper 369.

Gradstein, F. M., Ogg, J. G., Smith, A. G., Agterberg, F. P., Bleeker, W., Cooper, R. A., Davydov, V., Gibbard, P., Hinnov, L. A., House, M. R., Lourens, L., Luterbacher, H. P., McArthur, J., Melchin, M. J., Robb, L. J., Shergold, J. Villeneuve, M., Wardlaw, B. R., Ali, J., Brinkhuis, H., Hilgen, F.J., Hooker, J., Howarth, R.J., Knoll, A. H., Laskar, J., Monechi, S., Plumb, K. A., Powell, J., Raffi, I., Röhl, U., SAdler, P., SANfilipPo, A., Schmitz, B., Shackleton, N.J., Shields, G. A., Strauss, H., Van Dam, J., Van Kolfschoten, T., Veizer, J. \& Wilson, D. (2004). A Geologic Time Scale 2004. Cambridge University Press, Cambridge.

Harrison, G. J. O. (1982). The earliest parrot: a new species from the British Eocene. Ibis 124, 203-210.
Harrison, G. J. O. (1984). A revision of the fossil swifts (Vertebrata, Aves, suborder Apodi), with descriptions of three new genera and two new species. Mededelingen Werkgroep voor Tertiaire en Kwartaire Geologie 21, 157-177.

Harrison, C. J. O. \& Walker, C. A. (1977). Birds of the British Lower Eocene. Tertiary Research Special Paper 3, 1-52.

Heilmann-Glausen, C. \& Schmitz, B. (2000). The late Paleocene thermal maximum $\delta^{13} \mathrm{G}$ Denmark? Geologiska Föreningen $i$ Stockholm Förhandlinger 122, 70

Heissig, K. (1979). Die hypothetische Rolle Sudosteuropas bei den Säugetierwanderungen im Eozän und Oligozän. Neues Fahrbuch für Geologie und Paläontologie, Monatsheft 1979, 83-96.

Hesse, A. (1990). Die Beschreibung der Messelornithidae (Aves: Gruiformes: Rhynocheti) aus dem Alttertiär Europas und Nordamerikas. Courier Forschungsinsitut Senckenberg 128, 1-176.

Hoch, E. (1972). Fortidsfugle: også i Danmark. VARV 1972, 3-7.

Hoch, E. (1975). Amniote remains from the eastern part of the Lower Eocene North Sea Basin. Colloque International Centre National Researche Scientifique (Paris 1973) 218, 543-562.

Hoch, E. (1997). Notes on palaeornithology and on a new bird from the early Tertiary North Sea region. Geological Society of Denmark, Online Series 1. http://www.2dgf.dk/online/bird.htm

Hoch, E. \& Pedersen, S. S. (1983). En gammel fugl. VARV 1983 , 99-107.

Hooker, J. J. (1992). British mammalian paleo-communities across the Eocene-Oligocene transition and their environmental implications. In Eocene-Oligocene Climatic and Biotic Evolution (eds. D. R. Prothero and W. A. Berggren), pp. 494-515. Princeton University Press, Princeton.

Hope, S. (2002). The Mesozoic radiation of Neornithes. In Mesozoic Birds. Above the Heads of Dinosaurs (eds. L. M. Chiappe and L. M. Witmer), pp. 339-388. University of California Press, Berkeley.

Hou, L. \& Ericson, P. G. P. (2002). A Middle Eocene shorebird from China. The Condor 104, 896-899.

Houde, P. (1988). Paleognathous birds from the early Tertiary of the Northern Hemisphere. Publications of the Nuttal Ornithological Club 22, 1-148.

Houde, P. \& Olson, S. L. (1992). A radiation of coly-like birds from the Eocene of North America. Contributions in Science, Natural History Museum of Los Angeles County 36, 137-160.

Kelly, D. G., Bralower, T.J., Zachos, J. C., Silva, I. P. \& Thomas, E. (1996). Rapid diversification of planktonic foraminifera in the tropical Pacific (ODP site 865) during the late Paleocene thermal maximum. Geology 24, 423-426.

Kennett, J. P. (1977). Cenozoic evolution of Antarctic glaciation, the Circum-Antarctic Ocean, and their impact on global paleoceanography. Fournal of Geophysical Research 82, 3843-3860.

Kennett, J. P. \& Stott, L. D. (1990). Proteus and Proto-Oceanus: ancestral Paleogene oceans as revealed from Antarctic stable isotopic results; ODP Leg 113. Proceedings of the Ocean Drilling Program, Scientific Results 113, 865-880.

Kennett, J. P. \& Stotт, L. D. (1991). Abrupt deep-sea warming, palaeoceanographic changes and benthic extinctions at the end of the Palaeocene. Nature 353, 225-229.

Kristoffersen, A. V. (1997a). Flight apparatus of Paleocene/ Eocene birds from the Fur Formation of Denmark. Aarhus Geoscience 6, 49-53.

Kristoffersen, A. V. (1997 b). New records of perching birds from the latest Palaeocene/earliest Eocene Fur Formation of Denmark. Geological Society of Denmark, Online Series 1, http:// www.2dgf.dk/online/anette.htm 
Kristoffersen, A. V. (1999). Lithornithid birds (Aves, Palaeognathae) from the Lower Palaeogene of Denmark. Geologie en Mijnbouw 78, 375-381.

Kristoffersen, A. V. (2002a). An early Paleogene trogon (Aves: Trogoniformes) from the Fur Formation, Denmark. Fournal of Vertebrate Paleontology 22, 661-666.

Kristoffersen, A. V. (2002b). The avian diversity in the latest Paleocene - earliest Eocene Fur Formation, Denmark. A synopsis. Unpublished Ph.D. thesis, Geological Institute, University of Copenhagen, Denmark.

Larsen, L. M., Fitton, J. G. \& Pedersen, A. K. (2003). Paleogene volcanic ash layers in the Danish Basin: compositions and source areas in the North Atlantic Igneous Province. Lithos 71 , $47-80$.

Legendre, S. (1987). Concordance entre paléontologie continentale et les événements paléocéanographigues: exemple des faunes de mammifères du Paléogène du Quercy. Comptes Rendus Hebdomadaires des Seances de l'Academie des Sciences (ser. 3) 304, $45-50$.

Legendre, S. (1988). Le gisement du Bretou (Phosphorites du Quercy, Tannet-Garonne, France) et sa faune de vertebras de l'Eocene. Palaeontographica Abteilung A 205, 173-182.

Legendre, S. \& Hartenberger, J.-L. (1992). The evolution of mammalian faunas in Europe during the Eocene and Oligocene. In Eocene-Oligocene Climatic and Biotic Evolution (eds. D. R. Prothero and W. A. Berggren), pp. 516-528. Princeton University Press, Princeton.

Leonard, L. M., Dyke, G. J. \& Van Tuinen, M. (2005). A new specimen of the fossil palaeognath Lithornis from the Lower Eocene of Denmark. American Museum Novitates 3491, 1-11.

Livezey, B. C. (1997). A phylogenetic analysis of basal Anseriformes, the fossil Presbyornis and the interordinal relationships of waterfowl. Zoological Fournal of the Linnean Society 121, $361-428$.

Livezey, B. C. (1998). A phylogenetic analysis of the Gruiformes (Aves) based on morphological characters, with an emphasis on the rails (Rallidae). Philosophical Transactions of the Royal Society, Series B 353, 2077-2151.

MaYR, G. (1998a). A new family of Eocene zygodactyl birds. Senckenbergiana lethaea 78, 199-209.

MaYr, G. (1998b). 'Coraciiforme' und 'piciforme' Kleinvögel aus dem Mittel-Eozän der Grube Messel (Hessen, Deutschland). Courier Forschungsinstitut Senckenberg 205, 101 pp.

Mayr, G. (1999). A new trogon from the Middle Oligocene of Céreste, France. The Auk 116, 427-434.

Mayr, G. (2000). Charadriiform birds from the Early Oligocene of Céreste (France) and the Middle Eocene of Messel (Hessen, Germany). Geobios 33, 625-636.

Mayr, G. (2001). Comments on the systematic position of the Lower Eocene parrot Pulchrapollia gracilis. Senckenbergiana lethaea 81, 339-341.

MaYR, G. (2002a). On the osteology and phylogenetic affinities of the Pseudasturidae - Lower Eocene stem-group representatives of parrots (Aves, Psittaciformes). Zoological Fournal of the Linnean Society 136, 715-729.

MAYr, G. (2002b). Osteological evidence for paraphyly of the avian order Caprimulgiformes (nightjars and allies). Journal für Ornithologie 143, 82-97.

MaYr, G. (2003). Phylogeny of Early Tertiary swifts and hummingbirds (Aves: Apodiformes). The Auk 120, 145-151.

Mayr, G. (2004a). Old World fossil record of modern-type Hummingbirds. Science 304, 861-864.
Mayr, G. (2004b). Phylogenetic relationships of the early Tertiary Messel rails (Aves, Messelornithidae). Senckenbergiana Lethaea 84, 317-322.

Mayr, G. (2005). The Paleogene fossil record of birds in Europe. Biological Reviewes 80, 1-28.

Mayr, G. \& Clarke, J. (2003). The deep divergences of neornithine birds: a phylogenetic analysis of morphological characters. Cladistics 19, 527-553.

Mayr, G. \& Daniels, M. (1998). Eocene parrots from Messel (Hessen, Germany) and the London Clay of Waltonon-the-Naze (Essex, England). Senckenbergiana Lethaea 78, 157177.

Mayr, G., Manegold, A. \& Johansson, U. (2003). Monophyletic groups within 'higher land birds' - comparison of morphological and molecular data. Fournal of Zoological Systematics and Evolutionary Research 41, 233-248.

Mayr, G. \& Mourer-Chauviré, C. (2004). Unusual tarsometatarsus of a mousebird from the Paleogene of France and the relationships of Selmes Peters, 1999. Journal of Vertebrate Paleontology 24, 366-372.

Mayr, G. \& Peters, D. S. (1998). The mousebirds (Aves: Coliiformes) from the Middle Eocene of Grube Messel (Hessen, Germany). Senckenbergiana Lethaea 78, 179-197.

Mayr, G. \& Weidig, I. (2004). The Early Eocene bird Gallinuloides wyomingensis - a stem group representative of Galliformes. Acta Palaeontologica Polonica 49, 211-217.

McKenna, M. C. (1980). Eocene paleolatitude, climate and mammals of Ellesmere Island. Palaeogeography, Palaeoclimatology, Palaeoecology 30, 349-362.

McKenna, M. C. (1983). Cenozoic paleogeography of North Atlantic land bridges. In Structure and Development of the Greenland-Scotland Ridge (eds. M. H. P. Bott, S. Saxov, M. Talwani and J. Theide), pp. 351-400, NATO Conference Series IV, Marine Sciences 8.

MiLLER, K. G. (1992). Middle Eocene to Oligocene stable isotopes, climate and deep-water history: the Terminal Eocene Event? In Eocene-Oligocene Climatic and Biotic Evolution (eds. D. R. Prothero and W. A. Berggren), pp. 160-177. Princeton University Press, Princeton.

Miller, K. G., Fairbanks, R. G. \& Mountain, G. S. (1987). Tertiary oxygen isotope synthesis, sea level history, and continental margin erosion. Paleoceanography 2, 1-19.

Miller, K. G., Wright, J. D. \& Fairbanks, R. G. (1991). Unlocking the Ice House: Oligocene-Miocene oxygen isotopes, eustasy and margin erosion. Fournal of Geophysical Research 96, 6829-6848.

Muíkovsky, J. (1996). Tertiary avian localities of Europe. Acta Universitas Carolinae, Geologica 39, 1-846.

Monroe, B. L. \& Sibley, C. G. (1993). A World Checklist of Birds. Yale University Press, New Haven.

Mourer-Chauviré, C. (1992). The Galliformes (Aves) from the Phosphorites du Quercy (France): systematics and biostratigraphy. Natural History Museum of Los Angeles County Science Series 36, 67-95.

Mourer-Chauviré, G. (1995). The Messelornithidae (Aves: Gruiformes) from the Paleogene of France. Courier Forschungsinstitut Senckenberg 181, 95-105.

Mourer-Chauviré, C., Berthet, D. \& Hugueney, M. (2004). The late Oligocene birds of the Créchy quarry (Allier, France), with a description of two new genera (Aves: Pelecaniformes: Phalacrocoracidae, and Anseriformes: Anseranatidae). Senckenbergiana Lethaea 84, 303-315. 
Olson, S. L. (1985). The fossil record of birds. In Avian Biology, Vol. 8 (eds. D. S. Farner, J. R. King and K. C. Parkes), pp. 79-238. Academic Press, New York.

Olson, S. L. \& Parris, D. C. (1987). The Cretaceous birds of New Jersey. Smithsonian Contributions to Paleobiology 63, 1-22.

Owen, R. (1841). Description of the fossil remains of a mammal (Hyracotherium leporinum) and of a bird (Lithornis vulturinus) from the London clay. Transactions of the Geological Society of London 6, 203-208.

Paton, T., Baker, A. J., Groth, J. F. \& Barrowclough, G. F. (2003). RAG-1 sequences resolve phylogenetic relationships within Charadriiform birds. Molecular Phylogenetics and Evolution 29, 268-278.

Pedersen, G. K. \& Buchardt, B. (1996). The calcareous concretions (cementsten) in the Fur Formation (Paleogene, Denmark): isotopic evidence of early diagenetic growth. Bulletin of the Geological Society of Denmark 43, 78-86.

Pedersen, G. K., Pedersen, S. A. S., Steffensen, J. \& Pedersen, C. P. (2004). Clay content of a clayey diatomite, the Early Eocene Fur Formation, Denmark. Bulletin of the Geological Society of Denmark 51, 159-177.

Pedersen, G. K. \& Surlyk, F. (1983). The Fur Formation, a late Paleocene ash-bearing diatomite from northern Denmark. Bulletin of the Geological Society of Denmark 32, 43-65.

Poe, S. \& Chubb, A. L. (2004). Birds in a bush: five genes indicate explosive evolution of avian orders. Evolution 58, 404-415.

Prothero, D. R. (1994a). The Eocene-Oligocene Transition: Paradise Lost. Columbia University Press, New York.

Prothero, D. R. (1994b). The late Eocene-Oligocene extinctions. Annual Reviewes of Earth and Planetary Sciences 22, 145-165.

Schmitz, B., Peucker-Ehrenbrinck, B., Heilmann-Glausen, G., Åberg, G., Asaro, F. \& Lee, C.-T. A. (2004). Basaltic explosive volcanism, but no comet impact, at the Paleocene-Eocene boundary: high-resolution chemical and isotopic records from Egypt, Spain and Denmark. Earth and Planetary Science Letters 225, $1-17$.

Stegmann, B. (1964). Die funktionelle Bedeutung des Schlüsselbeines bei den Vögeln. Fournal für Ornithologie 105, 450-463.

Stehlin, H. G. (1909). Remarques sur les faunules de mammifères des couches éocènes et oligocènes du Bassin de Paris. Bulletin de la Société Geologique de France 9, 488-520.

Svensen, H., Planke, S., Malthe-Sørenssen, A., Jamtveit, B., Myklebust, R., Eidem, T. R. \& Rey, S. S. (2004). Release of methane from a volcanic basin as a mechanism for initial Eocene global warming. Nature 429, 542-545.

Talwani, M. \& Eldholm, O. (1977). Evolution of the NorwegianGreenland Sea. Geological Society of America Bulletin 88, 969-999.

Thiede, J., Eldholm, O. \& Taylor, E. (1989). Variability of Cenozoic Norwegian-Greenland Sea, paleoceanography and northern hemisphere paleoclimate. Proceedings of the Ocean Drilling Program, Scientific Results 104, 1067-1118.

Thomas, D. J. (1998). Biogeography of the late Paleocene benthic foraminiferal extinction. In Late Paleocene-Early Eocene Climatic and Biotic Events in the Marine and Terrestrial Records (eds. M.-P. Aubry, S. G. Lucas and W. A. Berggren), pp. 214-243. Columbia University Press, New York.

Thomas, D.J., Zachos, J. C., Bralower, T.J., Thomas, E. \& Bohaty, S. (2002). Warming the fuel for the fire: evidence for the thermal dissociation of methane hydrate during the Paleocene-Eocene thermal maximum. Geology 30, 1067-1070.

Unwin, D. M. (1993). Aves. In The Fossil Record II (ed. M.J. Benton), pp. 717-737. Chapman and Hall, London.

Zachos, J., Pagani, M., Sloan, L., Thomas, E. \& Billups, K. (2001). Trends, rhythms, and aberrations in global climate 65 Ma to present. Science 292, 686-693. 